\title{
ANALISIS POTENSI KEBANGKRUTAN BANK UMUM SYARIAH DI INDONESIA PADA PERIODE 2012- 2016 DENGAN METODE MULTIPLE DISCRIMINANT ANALYSIS
}

Raditya Prawita Jati

Mahasiswa Program Studi S1 Ekonomi Islam Fakultas Ekonomi dan Bisnis Universitas Airlangga Email: raditypj@gmail.com

Dr. Ari Prasetyo, S.E., M.Si

Departemen Ekonomi Syariah Fakultas Ekonomi dan Bisnis Universitas Airlangga

Email: ari.prasetyo@feb.unair.ac.id

\begin{abstract}
This study aims to see the health level of sharia commercial banks. This study uses a sample of 10 sharia banks that publish annual financial statements in the period 2012-2016. This study uses secondary data by collecting annual financial statements for the period 2012-2016. The analysis model used is multiple discriminant analysis. Multiple discriminant analysis measurement methods will be represented by net working capital ratio to total assets, retained earnings to total assets, profit before tax to total assets, and book value of capital to book value of debt.
\end{abstract}

Keywords:. Shariah Bank, Bankruptcy, Altman Z-Score, financial distress, Multiple Discriminant Analysis

\section{PENDAHULUAN}

Fenomena kebangkrutan bank pada saat krisis ekonomi tahun 1998 memunculkan sebuah fakta menarik. (Abrori, 2015:8). Dalam website Profil Bank Muamalat, Bank Muamalat sebagai satusatunya Bank Syariah pada saat krisis 1998 juga hampir ditutup jika tidak di-bailout atau diberi suntikan dana oleh Islamic Development Bank (Prasdiwi, 2017:4). Kesulitan keuangan yang dialami Bank Muamalat tersebut membantah anggapan sebagian besar praktisi kevangan syariah yang mengatakan bahwa bank syariah kebal terhadap krisis (Kurniawan, 2016:4). Ini memang membuktikan bahwa meskipun pada masa krisis keuangan, perbankan syariah dapat bertahan dan mengatasi masalahmasalah yang terjadi dalam kegiatan usahanya. Namun Bank Syariah tetaplah sebuah lembaga keuangan yang profit oriented yang tetap rentan jika dihadapkan dengan situasi krisis dan akan tetap menghadapi berbagai resiko yang tidak menutup kemungkinan mengancam eksistensinya.

Bank syariah yang meskipun bisa terpengaruh krisis global, namun tidak terlalu mengalami dampak negatif dari krisis global. Ini karena bank syariah tidak rentan dengan fluktuasi tingkat suku bunga, karena bank syariah beroperasi tidak berdasarkan sistem bunga maka bank syariah tidak terkena dampak langsung dari negative spread dan terbebas dari resiko suku bunga. Tetapi masih banyak resiko lain yang tetap harus ditanggung bank syariah. Misalnya, penurunan aktivitas perekonomian pada saat krisis akan berakibat menurunnya profit usaha,yang pada akhirnya menurunkan tingkat bagi hasil yang bisa diberikan bank syariah. Jika aktivitas ekonomi menurun sangat tajam, maka

1) Jurnal ini merupakan bagian dari skripsi dari Raditya Prawita Jati, NIM : 041311433032. 
Jati, et al/Jurnal Ekonomi Syariah Teori dan Terapan Vol. 5 No. 11 November 2018:937-954; ANALISIS POTENSI KEBANGKRUTAN BANK UMUM SYARIAH DI INDONESIA PADA PERIODE 20122016 DENGAN METODE MULTIPLE DISCRIMINANT ANALYSIS

bagi hasil yang bisa diberikan oleh bank

syariah menjadi sangat kecil. Dampak ini

bisa membingungkan bank syariah karena

bank syariah hanya memiliki dua pilihan

yaitu memangkas margin keuntungannya

demi mempertahankan bagian nasabah,

atau kehilangan nasabah.

Pada 2010 sampai akhir tahun 2013 perbankan syariah memang terus tumbuh signifikan. Dana pihak ketiga (DPK) dan pembiayaan yang diberikan (PYD) bank syariah juga mengalami tren kenaikan selama periode 2010 sampai 2013. Pembiayaan bermasalah yang dihitung dengan rasio Non Performing Financing (NPF) dapat dijaga sesuai ketentuan Bank Indonesia yaitu dibawah 5\%. Kemampuan bank syariah dalam menghasilkan laba yang dihitung dengan rasio return on asset (ROA) juga semakin meningkat pesat. Pada saat itu bank umum syariah di Indonesia berjumlah 11. Pertumbuhan perbankan syariah yang menjanjikan saat itu menyebabkan pada tahun 2014 terdapat satu bank umum syariah baru sehingga menjadi 12. Namun pada tahun 2014 dan 2015 terjadi perlambatan pada kinerja perbankan syariah yang bisa dilihat dari menurunnya pertumbuhan asset, pembiayaan yang diberikan (PYD), dan dana pihak ketiga (DPK). Penurunan juga bisa dilihat dari rasio likuiditas yaitu financing to deposit ratio (FDR) dan rasio profitabilitas yaitu return on asset (ROA), selain itu rasio pembiayaan bermasalah atau non performing financing (NPF) mengalami peningkatan hingga mendekati 5\%. Hal ini terjadi karena krisis kevangan di Tiongkok sebagai pengguna komoditas sumber daya alam terbesar, pelemahan ekonomi domestik Tiongkok menyebabkan permintaan terhadap komoditas global menurun.

Dari tahun ke tahun jumlah bank umum syariah di Indonesia mengalami peningkatan dimana pada tahun 2008 hanya ada 5 unit sedangkan sekarang , sampai bulan Januari 2017 bank syariah yang ada di Indonesia sudah sebanyak 13 unit (OJK, 2017). Untuk unit usaha syariah memang mengalami penurunan, ini karena ada beberapa unit usaha syariah yang telah berubah menjadi bank umum syariah dan untuk jumlah Bank Pembiayaan Rakyat Syariah (BPRS) sama seperti bank umum syariah juga terus mengalami peningkatan. Bertambahnya jumlah Bank Umum Syariah harus disertai dengan evaluasi terhadap kejadian pelambatan pertumbuhan bank syariah agar tidak terjadi kebangkrutan. Pertumbuhan jumlah bank syariah yang begitu pesat ini menciptakan persaingan yang ketat antar bank syariah, yang dikhawatirkan akhirnya menciptakan praktik-praktik yang tidak sehat. Seperti bank syariah hanya terfokus untuk mengumpulkan dana sebanyakbanyaknya tanpa memikirkan kemana dana tersebut harus disalurkan. Oleh karena itu prediksi kebangkrutan pada bank syariah ini sangat diperlukan. Kebangkrutan merupakan masalah yang sangat esensial yang harus 
Jati, et al/Jurnal Ekonomi Syariah Teori dan Terapan Vol. 5 No. 11 November 2018:937-954;

ANALISIS POTENSI KEBANGKRUTAN BANK UMUM SYARIAH DI INDONESIA PADA PERIODE 2012 2016 DENGAN METODE MULTIPLE DISCRIMINANT ANALYSIS

diwaspadai oleh setiap perusahaan.

Kebangkrutan pada suatu perusahaan akan menimbulkan berbagai permasalahan seperti meningkatnya angka pengangguran, meningkatnya angka kriminalitas, berkurangnya pendapatan Negara, serta dampak lain pada perusahaan yang selama ini menjadi mitra kerja perusahaan yang mengalami kebangkrutan. Dampak negatif tersebut dapat diminimalisir apabila hal tersebut dapat diprediksi sebelumnya.

Kemampuan dalam memprediksi mengenai perusahaan yang mengalami kesulitan keuangan (financial distress) yang kemudian mengalami kebangkrutan merupakan salah satu analisis yang penting bagi pihak-pihak yang berkepentingan seperti kreditur, investor, otoritas pembuat peraturan, auditor, maupun manajemen (Agus Sartono, 2008:112). Bagi kreditur analisis ini menjadi bahan pertimbangan utama dalam memutuskan untuk menarik piutangnya, menambah piutang untuk mengatasi masalah tersebut, ataupun mengambil kebijakan lain. Sementara dari sisi investor hasil analisisnya akan digunakan untuk menentukan sikap terhadap sekuritas yang dimiliki pada perusahaan dimana dia akan berinvestasi (Sartono,2008:113). Risiko kebangkrutan bagi perusahaan sebenarnya dapat dilihat dan diukur melalui laporan keuangan, dengan cara melakukan analisis terhadap laporan keuangan yang dikeluarkan oleh perusahaan yang bersangkutan (Thohari, 2015). Analisis laporan keuangan merupakan alat untuk mengetahui posisi kevangan serta hasil-hasil yang telah dicapai perusahaan. Tingkat kesehatan perusahaan penting artinya bagi perusahaan untuk meningkatkan efisiensi dalam menjalankan usahanya, sehingga kemampuan untuk memperoleh keuntungan dapat ditingkatkan yang akhirnya dapat menghindari adanya kemungkinan kebangkrutan suatu perusahaan. Prediksi kebangkrutan dapat dibuktikan dengan menggunakan rasiorasio keuangan. Menurut Agus Sartono (2008:115) Rasio keuangan dapat digunakan sebagai alat prediksi kegagalan perusahaan meskipun tidak semua rasio dapat memprediksi dengan sama baiknya dan tidak dapat memprediksi dengan tingkat keberhasilan yang sama. Studi mengenai kebangkrutan perusahaan pertama kali dikemukakan oleh Beaver pada tahun 1966. Beaver menggunakan 29 rasio keuangan perusahaan pada lima tahun sebelum terjadinya kebangkrutan. Tujuan penelitiannya yaitu untuk mengetahui apakah rasio-rasio keuangan terpilih bisa digunakan untuk memprediksi kebangkrutan dan berapa lama kebangkrutan tersebut akan terjadi setelah rasio-rasio keuangan mengalami penurunan atau menjadi tidak sehat. Analisis rasio keuangan untuk memprediksi kebangkrutan perusahaan 
Jati, et al/Jurnal Ekonomi Syariah Teori dan Terapan Vol. 5 No. 11 November 2018:937-954; ANALISIS POTENSI KEBANGKRUTAN BANK UMUM SYARIAH DI INDONESIA PADA PERIODE 20122016 DENGAN METODE MULTIPLE DISCRIMINANT ANALYSIS

menjadi sangat menarik setelah Altman

pada tahun 1968 menemukan suatu formula untuk memprediksi kebangkrutan dengan istilah yang sangat terkenal, yang disebut Z-Score. Penggunaan model Altman banyak digunakan oleh para praktisi dalam memprediksi kebangkrutan suatu perusahaan (Agustina dan Rahmawati, 2010).

Kelebihan dari analisis Z-Score ini adalah bahwa dengan mengetahui nilai $Z$ dari perusahaan dengan metode diskriminan kebangkrutan Altman, maka dapat diketahui tingkat kesehatan keuangan perusahaannya. Selain itu jika nilai $Z$ perusahaan termasuk dalam kategori bangkrut atau kritis (rawan), maka perusahaan masih bisa memperbaiki kesehatan keuangan perusahaan dengan segera. Sehingga dengan mengetahui nilai $Z$ ini maka kondisi keuangan perusahaan akan semakin kuat dan kebangkrutan dapat diantisipasi sedini mungkin (early warning system).

Dalam penelitian ini model Altman Z-Score yang digunakan adalah model Altman Z-Score modifikasi. Model Altman Z-Score modifikasi ini dapat digunakan pada semua perusahaan seperti manufaktur, non manufaktur dan perusahaan penerbit obligasi di Negara berkembang (emerging market) ( Ramadhani dan Lukviarman, 2009). Ini karena dalam model Altman modifikasi variabel X5 (sales to total assets) dihilangkan, karena perusahaan non manufaktur tidak mempunyai akun sales (penjualan) dan mengganti X4 (market value of equity to book value of debt) menjadi book value of equity to book value of debt (nilai buku ekuitas terhadap total kewajiban), dikarenakan banyak industri yang belum listing di bursa saham sehingga belum mempunyai nilai pasar saham.

Berdasarkan latar belakang tersebut maka penulis tertarik untuk mengadakan penelitian dengan judul

"MENILAI KESEHATAN BANK MELALUI METODE MULTIPLE DISCRIMINANT ANALYSIS PADA BANK UMUM SYARIAH DI INDONESIA PERIODE 2012-2016"

\section{LANDASAN TEORI}

Menurut undang-undang No. 21 tahun 2008 pasal 1 ayat 7 mengatakan bahwa bank syariah adalah bank yang menjalankan kegiatan usahanya berdasarkan Prinsip Syariah dan menurut jenisnya terdiri atas Bank Umum Syariah dan Bank Pembiayaan Rakyat Syariah. Bank islam atau selanjutnya disebut dengan bank syariah adalah bank yang beroperasi dengan tidak mengandalkan pada bunga. Bank islam atau biasa disebut bank tanpa bunga, adalah lembaga/perbankan yang operasionalnya dan produknya dikembankan berlandaskan Al-Quran dan Hadist Nabi Saw. Atau dengan kata lain, bank islam adalah lembaga keuangan yang usaha pokoknya memberikan pembiayaan disesuaikan dengan prinsip syariat islam (Muhamad, 2014:2). Seperti 
Jati, et al/Jurnal Ekonomi Syariah Teori dan Terapan Vol. 5 No. 11 November 2018:937-954;

ANALISIS POTENSI KEBANGKRUTAN BANK UMUM SYARIAH DI INDONESIA PADA PERIODE 20122016 DENGAN METODE MULTIPLE DISCRIMINANT ANALYSIS

yang dijalaskan surat Al-Baqarah ayat 278

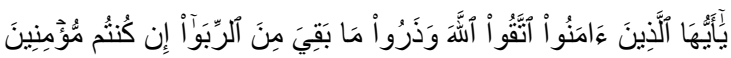

rYA

Yāay-yuhal-lażīna āmanūt-taqūl-

Lāha ważarū mā baqiya minar-ribā in kuntum mu'minīn.

"Hai orang-orang yang beriman, bertakwalah kepada Allah dan tinggalkan sisa riba (yang belum dipungut) jika kamu orang-orang yang beriman (Al-Baqarah: 278)"

Kebangkrutan merupakan suatu kondisi di saat perusahaan sedang mengalami ketidakcukupan dana untuk melakukan usahanya. Menurut Undang undang Kepailitan No. 4 Tahun 1998, debitur yang mempunyai dua atau lebih kreditur dan tidak membayar sedikitnya satu utang yang telah jatuh waktu dan dapat ditagih, dinyatakan pailit dengan putusan pengadilan yang berwenang, baik atas permohonannya sendiri, maupun atas permintaan seorang atau lebih krediturnya. Kebangkrutan dapat diartikan sebagai kegagalan perusahaan dalam menjalankan operasi perusahaan untuk menghasilkan laba (Adnan dan Kurniasih, 2000: 137). Kebangkrutan sering disebut likuidasi perusahaan atau penutupan perusahaan atau insovabilitas.

Faktor- faktor yang menyebabkan bangkrutnya sebuah perusahaan ada bermacam-macam dan sangatlah berbeda antara perusahaan satu dengan perusahaan lainnya. Tetapi pada umumnya kebangkrutan terjadi karena masalah internal yang timbul dalam perusahaan itu sendiri. Beberapa contoh masalah internal perusahaan yaitu :

1. Ketidakseimbangan keahlian dalam manajemen puncak, manajemen puncak harus dikuasai oleh semua bidang tidak hanya dari bidang tertentu saja karena bisa menyebabkan ketidakpahaman dalam menyelesaikan masalah karena bukan ahlinya.

2. Pimpinan yang sering mengabaikan saran-saran dari mitra perusahaan bisa membahayakan keberlangsungan perusahaan.

3. Dewan direktur yang kurang aktif dan tidak tahu apa-apa menyebabkan masalah baru diketahui mereka apabila kebangkrutan sudah dekat.

4. Kurangnya tanggung jawab pimpinan puncak yang merasa tidak harus mempertanggung jawabkan segala tindakannya bisa menghancurkan perusahaan.

Dari sisi finansial kebangkrutan terjadi karena :

1. Hutang yang terlalu besar menyebabkan beban yang berat bagi perusahaan.

2. Terjadinya "current liabilities" yang sangat besar jika dibandingkan dengan "current assets".

3. Banyaknya piutang yang tidak tertagih.

4. Kesalahan dalam kebijakan deviden Selain karena faktor internal, faktor eksternal atau sebab yang timbul dari luar 
Jati, et al/Jurnal Ekonomi Syariah Teori dan Terapan Vol. 5 No. 11 November 2018:937-954;

ANALISIS POTENSI KEBANGKRUTAN BANK UMUM SYARIAH DI INDONESIA PADA PERIODE 20122016 DENGAN METODE MULTIPLE DISCRIMINANT ANALYSIS

perusahaan yang berada diluar

kekuasaan atau kontrol pimpinan

perusahaan juga dapat menyebabkan

kebangkrutan perusahaan. Faktor ini meliputi :

1. Adanya persaingan hebat antar perusahaan.

2. Berkurangnya permintaan terhadap produk perusahaan.

3. Turunnya harga dan lain sebagainya.

Menurut Pass \& Lowes dalam

Kamus Lengkap Ekonomi, insolvency or bankruptcy (ketidakmampuan membayar atau kebangkrutan) merupakan suatu kondisi dimana kewajiban (liabilities) seseorang atau perusahaan kepada kreditor melebihi aktivanya. Sehingga orang atau perusahaan tersebut tidak dapat membayar kembali semua kewajiban kumulatifnya dengan aktiva yang ada. Ketidakmampuan membayar terjadi setelah dalam periode pengeluaran seseorang melebihi pendapatannya, atau biaya-biaya suatu perusahaan melebihi penerimaan dari penjualannya (merugi (losses)). Lama kelamaan ketidakmampuan membayar akan menjadi kebangkrutan dan perlu adanya pengaturan likuidasi dari aktiva yang ada, yang nantinya hasil likuidasi akan dibagikan kepada kreditor.

Dapat disimpulkan bahwa prediksi kebangkrutan adalah suatu ramalan atau perkiraan dimana kondisi perusahaan tidak bisa memenuhi kewajibannya dengan aktiva yang dimiliki oleh perusahaan. Prediksi kebangkrutan harus dilakukan oleh semua perusahaan agar ada peringatan sebelum terjadinya kebangkrutan, dengan begitu perusahaan masih bisa mengambil langkah untuk menyelamatkan perusahaan.

Menurut Widarjono (2010: 167) analisis diskriminan adalah "metode teknik dependen dimana variabel dependennya bersifat non metrik". Menurutnya analisis diskriminan adalah kombinasi linear dari dua atau lebih variabel independen yang akan membedakan atau mendiskriminasikan dua objek atau lebih di dalam sebuah kelompok atau grup.

Model dasar analisis diskriminan memang mirip seperti regresi berganda, bedanya hanya bila variabel dependen regresi berganda dilambangkan dengan $Y$, maka analisis diskriminan dilambangkan dengan D. Perbedaan lainnya yaitu adalah bila regresi berganda variabel dependen harus metrik (interval dan rasio), sedangkan dalam analisis diskriminan variabel dependennya kategoris (Simamora, 2005: 144).

Altman menggunakan fungsi dari analisis diskriminan untuk memperkirakan kebangkrutan pada suatu perusahaan, model prediksi kebangkrutan yang dipakai adalah model Multiple Discriminant Analysis atau lebih dikenal dengan Z-Score. Analisis Z-Score ini dibuat untuk mengatasi keterbatasan dari analisis rasio keuangan karena dilakukan secara terpisah. 
Jati, et al/Jurnal Ekonomi Syariah Teori dan Terapan Vol. 5 No. 11 November 2018:937-954;

ANALISIS POTENSI KEBANGKRUTAN BANK UMUM SYARIAH DI INDONESIA PADA PERIODE 20122016 DENGAN METODE MULTIPLE DISCRIMINANT ANALYSIS

MDA (Multiple Discriminant

Analysis) adalah sebuah bentuk analisis diskriminan berganda atau dengan kata lain grup yang dimiliki sebagai variabel dependen bukan lagi dua, melainkan tiga, empat atau lebih. Dalam membangun modelnya Altman menggunakan rasio-rasio keuangan yang didasarkan pada popularitasnya dalam literatur dan relevansi terhadap penelitian, rasio yang digunakan juga memiliki lima kriteria yaitu rasio yang dapat mencerminkan likuiditas, profitabilitas, leverage, solvency, dan rasio aktifitas.

Awalnya Altman menguji 22 rasio keuangan dari 33 perusahaan manufaktur yang bangkrut dan 33 perusahaan yang tidak bangkrut pada tahun 1960 sampai 1965 dan pada akhirnya didapatkan lima rasio kevangan yang dikombinasikan dan dinilai paling berpengaruh untuk memprediksi potensi kebangkrutan perusahaan. Formula MDA pertama yang ditemukan oleh Altman (1968:594) ditulis sebagai berikut:

\section{$Z=1,2 X_{1}+1,4 X_{2}+3,3 X_{3}+0,6 x_{4}+1,0 x_{5}$}

Keterangan :

$$
\begin{aligned}
& Z=\text { overall index } \\
& X_{1}=\text { net working capital to total assets } \\
& X_{2}=\text { retained earning to total assets } \\
& X_{3}=\text { earning before interest to total } \\
& \text { assets }
\end{aligned}
$$$$
X_{4}=\text { market value of equity to total assets }
$$

$X_{5}=$ sales to total assets

Nilai $Z$ yang merupakan indeks keseluruhan fungsi multiple discriminant analysis. Dibagi kedalam tiga kategori keadaan, yaitu:

a. Nilai $Z<1,81$ maka perusahaan mengalami masalah kevangan yang serius atau bangkrut

b. Nilai $1,81<Z<2,90$ maka perusahaan masuk dalam grey area atau perusahaan tidak dapat dikatakan bangkrut tapi juga tidak dapat dikatakan sehat.

c. Nilai $Z>2,90$ maka perusahaan tidak mengalami masalah dengan kondisi kevangan atau tidak bangkrut.

Tahun 1984 Altman melakukan pengembangan model diskriminan alternatif Z-Score yang sebelumnya. Pada penelitian kali ini Altman melakukan penyesuaian agar model prediksi kebangkrutan ini dapat dipakai untuk perusahaan yang tidak mempunyai nilai pasar ekuitas atau perusahaan non go public. Perubahan atau revisi dilakukan pada variabel X4 dimana variabel sebelumnya merupakan nilai pasar ekuitas terhadap total kewajiban (market value of equity to book value of total debt) menjadi nilai buku ekuitas terhadap total kewajiban (book value of equity to book value of total debt) (Ibrah Musfa Kamal, 2012). Hasil revisi dari model Z-Score awal ini tidak hanya pada variabel rasio X4 saja tetapi juga pada nilai koefisien pada setiap variabel. Nilai $Z$ untuk model ini juga berbeda dari nilai $Z$ pada model 
Jati, et al/Jurnal Ekonomi Syariah Teori dan Terapan Vol. 5 No. 11 November 2018:937-954;

ANALISIS POTENSI KEBANGKRUTAN BANK UMUM SYARIAH DI INDONESIA PADA PERIODE 20122016 DENGAN METODE MULTIPLE DISCRIMINANT ANALYSIS

sebelumnya. Bentuk formula MDA atau Z-

$Z=6,56 X_{1}+3,26 X_{2}+6,72 X_{3}+$

Score hasil pengembangan Altman

(2000:20) adalah:

$Z=0,717 X_{1}+0,847 X_{2}+3,107 X_{3}+0,420 X_{4}$

$+0,998 X_{5}$

Kriteria nilai Z pada model ini lebih rendah

dari nilai sebelumnya yaitu:

a. Nilai $Z<1,23$ maka termasuk perusahaan yang bangkrut.

b. Nilai $1,23<Z<2,90$ maka perusahaan masuk dalam grey area,karena perusahaan tersebut tidak dapat dikatakan bangkrut tapi juga tidak dapat dikatakan sehat.

c. Nilai $Z>2,90$ maka perusahaan tersebut dikategorikan dalam keadaan sehat dan memiliki kemungkinan bangkrut yang rendah.

Menurut Ayu Suci Ramadhani dan

Niki Lukviarman (2009) Altman terus mengembangkan model analisis diskriminan alternatifnya, agar model prediksi kebangkrutannya dapat digunakan untuk semua jenis perusahaan,seperti perusahaan manufaktur, non manufaktur dan perusahaan penerbit obligasi di negara berkembang. Dalam Z-Score modifikasi ini Altman mengeliminasi variabel $X_{5}$ (sales/total assets) karena rasio ini sangat bervariatif pada industri dengan ukuran aset yang berbeda-beda. Maka, formula persamaan Z-Score yang telah di modifikasi oleh Altman dkk menunjukkan fungsi diskriminan sebagai berikut:

$1,05 \mathrm{X}_{4}$

Keterangan :

$\mathrm{X}_{1}=$ net working capital to total assets

$\mathrm{X}_{2}=$ retained earning to total assets

$\mathrm{X}_{3}=$ earning before interest and tax

tototal assets

$\mathrm{X}_{4}=$ book value of equity to book value of debt

$\mathrm{Z}$ = overall index

Kriteria nilai Z pada model Altman Modifikasi adalah :

a. Nilai $Z<1,23$ dikategorikan perusahaan yang diprediksi akan mengalami kebangkrutan

b. Nilai $1,23<Z<2,90$ dikategorikan dalam grey area, perusahaan mengalami sedikit masalah dengan kondisi keuangan meskipun tidak serius

Nilai Z $>2,90$ dikategorikan perusahaan yang tidak bangkrut.

\section{METODE PENELITIAN}

\section{Pendekatan Penelitian}

Dalam penelitian ini, pendekatan yang digunakan adalah pendekatan kuantitatif dengan jenis penelitian yang digunakan adalah penelitian dokumenter. Penelitian dokumenter adalah penelitian yang data dan informasinya diperoleh dari bahan dokumentasi institusi (Supardi, 
Jati, et al/Jurnal Ekonomi Syariah Teori dan Terapan Vol. 5 No. 11 November 2018:937-954;

ANALISIS POTENSI KEBANGKRUTAN BANK UMUM SYARIAH DI INDONESIA PADA PERIODE 20122016 DENGAN METODE MULTIPLE DISCRIMINANT ANALYSIS

2005:34). Setelah melakukan analisis

tersebut, kemudian dilakukan analisis

potensi kebangkrutan bank syariah

berdasarkan model Altman Z-Score yang kemudian hasilnya bisa menunjukkan potensi kebangkrutan.

\section{Definisi Operasional Variabel}

1. $X_{1}=$ Net Working Capital to Total Assets

Rasio ini dihitung dengan membagi modal kerja bersih dengan total aktiva. Modal kerja bersih (net working capital) diperoleh dengan cara aktiva lancar dikurangi dengan kewajiban lancar pada setiap bank umum syariah pada periode 20122016.

2. $X_{2}=$ Retained Earning to Total Assets

Rasio ini merupakan ukuran kumulatif keuntungan yang dihasilkan sebuah bank. Cara menghitung rasio ini dengan membagi laba ditahan dengan total aktiva pada setiap bank umum syariah di Indonesia periode 2012-2016. Rasio ini juga seperti memberi informasi mengenai berapa umur bank, karena semakin lama bank beroperasi memungkinkan untuk memperlancar akumulasi laba ditahan.

3. $X_{3}=$ Earning Before Taxes (EBT) to Total Assets

Dalam penelitian ini, hal yang menjadi objek penelitian adalah kondisi kevangan bank umum syariah. Sehingga tidak ada akun yang bernama EBIT dalam laporan kevangannya, karena dalam bank syariah tidak dikenal dengan sistem bunga, oleh karena itu akun dalam laporan keuangan bank umum syariah dikenal dengan akun Laba sebelum pajak penghasilan (earning before taxes). EBT diperoleh dari laba sebelum pajak penghasilan dibagi total aktiva pada setiap bank umum syariah di Indonesia periode 2012-2016.

4. $X_{4}=$ Book Value of Equity to Book Value of Total Debt

Rasio ini digunakan untuk menilai kemampuan perusahaan memenuhi kewajiban jangka panjang atau mengukur kemampuan permodalan perusahaan dalam menanggung seluruh kewajibannya. Namun, dalam penelitian ini karena ada beberapa bank umum syariah belum go public maka market value of equity dirubah menjadi book value of equity. Market value of equity to book value of total debt diperoleh dengan membagi nilai buku ekuitas dengan total kewajiban pada setiap bank umum syariah di Indonesia periode 20122016.

Jenis dan Sumber Data

Jenis data dalam penelitian ini menggunakan data sekunder yaitu laporan keuangan tahunan bank umum syariah yang diambil dan dikutip dari data-data yang sudah ada kemudian diolah dan dianalisis. Sumber data sekunder yang digunakan dalam penelitian ini yaitu laporan keuangan yang terdapat pada website Bank Indonesia dan laporan keuangan tahunan perbankan yang terdapat pada website bank bersangkutan. 
Jati, et al/Jurnal Ekonomi Syariah Teori dan Terapan Vol. 5 No. 11 November 2018:937-954;

ANALISIS POTENSI KEBANGKRUTAN BANK UMUM SYARIAH DI INDONESIA PADA PERIODE 20122016 DENGAN METODE MULTIPLE DISCRIMINANT ANALYSIS

Populasi dan Sampel

Populasi dalam penelitian ini adalah Bank Umum Syariah di Indonesia yang ada pada periode 2012-2016. Sampel merupakan bagian dari jumlah karakteristik yang dimiliki oleh populasi. Pada penelitian ini, teknik pengambilan sampel yang digunakan adalah purposive sampling. Anshori dan Iswati (2009:105) menyatakan bahwa sampling purposive adalah teknik penentuan sampel dengan pertimbangan tertentu. Beberapa pertimbangan untuk menetapkan kriteria sebagai berikut: Sampel yang digunakan adalah Bank Umum Syariah di Indonesia yang menerbitkan dan mempublikasikan laporan keuangan tahunannya selama periode 2012-2016. Sehingga total sampel ada sepuluh Bank Umum Syariah, yaitu Bank Muamalat Indonesia, Bank Syariah Mandiri, Bank Mega Syariah, Bank BRISyariah, Bank Syariah Bukopin, Bank BNI Syariah, Bank Jabar Banten Syariah, BCA Syariah, Maybank Syariah Indonesia dan Bank Panin Syariah.

\section{Teknik Analisis Data}

Teknis analisis data merupakan hal yang penting dalam suatu penelitian karena dengan melakukan analisis data maka peneliti akan lebih mudah memecahkan masalah penelitian. Penelitian ini memfokuskan pada bagaimana potensi kebangkrutan bank umum syariah di Indonesia berdasarkan metode Altman Z-Score modifikasi. Untuk menganalisis masalah yang telah dirumuskan dalam penelitian ini ditempuh dengan langkah-langkah sebagai berikut:

1. Menghitung variabel-variabel yang ada dalam rumus Altman Z-Score modifikasi dalam penelitian ini, antara lain :

a. Menghitung Net Working Capital to Total Assets

b. Menghitung Retained Earning to Total Assets

c. Menghitung Earning before tax to total assets

d. Menghitung Book value of equity to book value of debt

Hasil tersebut kemudian dimasukkan dalam rumus Altman Z-Score modifikasi. Setelah itu akan terlihat sesuai dengan hasil perhitungan yaitu perusahaan bangkrut, perusahaan mengalami masalah keuangan dan perusahaan tidak bangkrut.

\section{HASIL DAN PEMBAHASAN}

1. Net Working Capital to Total Assets Ratio

Nilai rasio net working capital to total assets bank umum syariah selama kurun waktu empat tahun terakhir menunjukkan nilai yang cenderung stabil. Hal ini menunjukkan bahwa kemampuan bank umum syariah dalam menghasilkan modal kerja bersih sama pada setiap bank. Jumlah atau nilai modal kerja bersih yang dihasilkan dari penggunaan aktiva yang dimiliki oleh bank umum syariah tersebut setiap tahunnya 
Jati, et al/Jurnal Ekonomi Syariah Teori dan Terapan Vol. 5 No. 11 November 2018:937-954;

ANALISIS POTENSI KEBANGKRUTAN BANK UMUM SYARIAH DI INDONESIA PADA PERIODE 2012 2016 DENGAN METODE MULTIPLE DISCRIMINANT ANALYSIS

juga hampir sama. Semakin tinggi

nilai rasio ini menunjukkan bank

umum syariah menghasilkan

modal kerja bersih yang tinggi dan

berakibat semakin tinggi pula tingkat likuiditas bank tersebut. Berdasarkan hal ini maka dapat dilihat bahwa bank umum syariah yang tingkat likuiditasnya sangat baik selama kurun waktu empat tahun terakhir adalah Panin Bank Syariah pada tahun 2014 dengan nilai 1.42. Artinya setiap pemakaian $\mathrm{Rp} 1$ aktiva yang dimiliki Panin Bank Syariah akan menghasilkan modal kerja bersih sebesar Rp 1.42.

2. Retained Earning to Total Assets Ratio

Perkembangan nilai rasio Retained Earning to Total Assets Ratio selama kurun waktu empat tahun terakhir pada setiap bank umum syariah menunjukkan nilai yang kecil cenderung konsisten. Selain itu dapat dilihat bahwa ada beberapa bank yang mempunyai nilai rasio negatif, yaitu Bank Syariah Bukopin yang dari tahun 2012 sampai tahun 2015 tetap mempunyai nilai yang minus. Hal yang sama juga terjadi pada Bank Jabar Banten Syariah yang mengalami nilai minus pada tahun 2012, tapi di tahun selanjutnya yaitu 2013-2015 nilai rasio retained earnings to total assets Bank Jabar
Banten Syariah mulai membaik dengan mendapatkan hasil yang positif. Dari sepuluh bank umum syariah selama empat tahun terakhir, nilai rasio retained earnings to total assets yang tertinggi dimiliki oleh Bank Maybank Syariah Indonesia pada tahun 2014 dengan nilai 0.093. Arti nilai 0.093 ini adalah setiap penggunaan Rp 1 aktiva oleh Bank Maybank Syariah Indonesia akan menghasilkan nilai laba ditahan sebesar Rp 0.093.

3. Earning Before Taxes (EBT) to Total Assets Ratio

Selama empat tahun terakhir bank yang nilai laba sebelum pajaknya tertinggi adalah Bank Syariah Mandiri, namun rasio laba sebelum pajak terhadap total aktiva yang terbesar adalah Bank Mega Syariah di tahun 2012 dengan nilai 0.302 . Artinya, setiap penggunaan Rp 1 aktiva yang dimilki Bank Mega Syariah akan menghasilkan nilai laba sebelum pajak sebesar Rp 0.302. Hal ini menunjukkan semakin tinggi nilai rasio laba sebelum pajak terhadap total aktiva maka menunjukkan semakin baiknya kinerja bank umum syariah dalam mengelola hartanya untuk menghasilkan laba sebelum pajak.

4. Book Value of Equity to Book Value of Total Debt Ratio 
Jati, et al/Jurnal Ekonomi Syariah Teori dan Terapan Vol. 5 No. 11 November 2018:937-954;

ANALISIS POTENSI KEBANGKRUTAN BANK UMUM SYARIAH DI INDONESIA PADA PERIODE 20122016 DENGAN METODE MULTIPLE DISCRIMINANT ANALYSIS

Rasio perbandingan antara nilai

buku ekuitas terhadap total kewajiban tertinggi pada tahun 2012 dan 2013 dimiliki oleh Bank Maybank Syariah Indonesia, tahun 2014 berpindah ke BRI Syariah dan untuk tahun 2015 dimiliki oleh Bank Maybank Syariah Indonesia. Semakin tinggi nilai rasio ini maka menunjukkan bank umum syariah mampu memenuhi seluruh kewajibannya dengan nilai buku ekuitas yang dimiliki oleh bankbank tersebut.

Setelah diperoleh rasio keuangan masing-masing bank, maka langkah penelitian selanjutnya adalah mengalikan rasio-rasio tersebut dengan koefisien yang telah ditentukan dalam rumus Altman ZScore dengan persamaan :

$Z=6,56 X_{1}+3,26 X_{2}+6,72 X_{3}+1,05 X_{4}$

Tabel 1. Perhitungan Z-Score BUS Tahun 2012

\begin{tabular}{|c|c|c|c|c|c|c|}
\hline No & $\begin{array}{c}\text { Bank } \\
\text { Umu } \\
\text { m } \\
\text { Syaria } \\
\text { h }\end{array}$ & $\begin{array}{c}6.5 \\
6 \\
X_{1}\end{array}$ & $\begin{array}{l}3,26 \\
X_{2}\end{array}$ & $\begin{array}{c}6.7 \\
2 \\
X_{3}\end{array}$ & $\begin{array}{c}1.0 \\
5 \\
X_{4}\end{array}$ & $\begin{array}{c}\text { Z- } \\
\text { Scor } \\
e\end{array}$ \\
\hline 1. & BNIS & $\begin{array}{c}5.7 \\
8\end{array}$ & 0.05 & $\begin{array}{c}0.0 \\
8\end{array}$ & $\begin{array}{c}0.5 \\
7\end{array}$ & 6.49 \\
\hline 2. & BSM & $\begin{array}{c}6.2 \\
0\end{array}$ & 0.16 & $\begin{array}{c}0.1 \\
3\end{array}$ & $\begin{array}{c}0.4 \\
7\end{array}$ & 6.98 \\
\hline 3. & BCAS & 6.0 & 0.03 & 0.0 & 1.2 & 7.37 \\
\hline
\end{tabular}

\begin{tabular}{|c|c|c|c|c|c|c|}
\hline & & 4 & & 4 & 4 & \\
\hline 4. & BSB & $\begin{array}{c}6.1 \\
1\end{array}$ & $\begin{array}{c}- \\
0.15\end{array}$ & $\begin{array}{c}0.0 \\
4\end{array}$ & $\begin{array}{c}0.0 \\
8\end{array}$ & 6.09 \\
\hline 5. & BMI & $\begin{array}{c}4.4 \\
4\end{array}$ & 0.08 & $\begin{array}{c}0.0 \\
7\end{array}$ & $\begin{array}{c}0.3 \\
1\end{array}$ & 4.91 \\
\hline 6. & BRIS & $\begin{array}{c}6.3 \\
0\end{array}$ & 0.02 & $\begin{array}{c}0.0 \\
6\end{array}$ & $\begin{array}{c}0.3 \\
2\end{array}$ & 6.72 \\
\hline 7. & BMS & $\begin{array}{c}5.6 \\
6\end{array}$ & 0.12 & $\begin{array}{c}2.0 \\
3\end{array}$ & $\begin{array}{c}0.3 \\
0\end{array}$ & 8.12 \\
\hline 8. & PBS & $\begin{array}{c}6.4 \\
5\end{array}$ & 0.05 & $\begin{array}{c}0.1 \\
4\end{array}$ & $\begin{array}{c}1.1 \\
9\end{array}$ & 7.84 \\
\hline 9. & BJBS & $\begin{array}{c}6.1 \\
8\end{array}$ & $\begin{array}{c}0.00 \\
7\end{array}$ & $\begin{array}{c}0.0 \\
3\end{array}$ & $\begin{array}{c}1.0 \\
9\end{array}$ & 7.24 \\
\hline No & $\begin{array}{c}\text { Bank } \\
\text { Umu } \\
\text { m } \\
\text { Syaria } \\
h\end{array}$ & $\begin{array}{c}6.5 \\
6 \\
X_{1}\end{array}$ & $\begin{array}{l}3,26 \\
X_{2}\end{array}$ & $\begin{array}{c}6.7 \\
2 \\
X_{3}\end{array}$ & $\begin{array}{c}1.0 \\
5 \\
X_{4}\end{array}$ & $\begin{array}{c}\text { Z- } \\
\text { Scor } \\
e\end{array}$ \\
\hline 10. & BMSI & $\begin{array}{c}6.4 \\
7\end{array}$ & 0.20 & $\begin{array}{c}1.8 \\
2\end{array}$ & $\begin{array}{c}1.8 \\
5\end{array}$ & $\begin{array}{c}10.3 \\
6\end{array}$ \\
\hline
\end{tabular}

Sumber: Data diolah

Nilai Z-Score dari keseluruhan bank umum syariah pada tahun 2012 melebihi nilai 2.9. Artinya seluruh bank umum syariah dikategorikan dalam keadaan tidak bangkrut. Pada tahun ini nilai Z-Score tertinggi adalah Bank Maybank Syariah Indonesia dan nilai Z-Score terendah adalah Bank Mualamat.

Tabel 2. Perhitungan Z-Score BUS Tahun 2013 
Jati, et al/Jurnal Ekonomi Syariah Teori dan Terapan Vol. 5 No. 11 November 2018:937-954;

ANALISIS POTENSI KEBANGKRUTAN BANK UMUM SYARIAH DI INDONESIA PADA PERIODE 20122016 DENGAN METODE MULTIPLE DISCRIMINANT ANALYSIS

\begin{tabular}{|c|c|c|c|c|c|c|}
\hline No & $\begin{array}{c}\text { Bank } \\
\text { Umum } \\
\text { Syaria } \\
\text { h }\end{array}$ & $\begin{array}{c}6.5 \\
6 \\
X_{1}\end{array}$ & $\begin{array}{c}3,2 \\
6 \\
X_{2}\end{array}$ & $\begin{array}{c}6.7 \\
2 \\
X_{3}\end{array}$ & $\begin{array}{c}1.0 \\
5 \\
X_{4}\end{array}$ & $\begin{array}{c}\text { Z- } \\
\text { Scor } \\
e\end{array}$ \\
\hline 1. & BNIS & $\begin{array}{c}6.0 \\
3\end{array}$ & $\begin{array}{c}0.0 \\
6\end{array}$ & $\begin{array}{c}0.0 \\
8\end{array}$ & $\begin{array}{c}0.3 \\
5\end{array}$ & 6.53 \\
\hline 2. & BSM & $\begin{array}{c}6.2 \\
1\end{array}$ & $\begin{array}{c}0.1 \\
7\end{array}$ & $\begin{array}{c}0.0 \\
9\end{array}$ & $\begin{array}{c}0.4 \\
6\end{array}$ & 6.94 \\
\hline 3. & BCAS & $\begin{array}{c}6.1 \\
8\end{array}$ & $\begin{array}{c}0.0 \\
5\end{array}$ & $\begin{array}{c}0.0 \\
5\end{array}$ & $\begin{array}{c}1.1 \\
9\end{array}$ & 7.48 \\
\hline 4. & BSB & $\begin{array}{c}6.0 \\
1\end{array}$ & $\begin{array}{c}- \\
0.1 \\
1\end{array}$ & $\begin{array}{c}0.0 \\
4\end{array}$ & $\begin{array}{c}0.0 \\
7\end{array}$ & 6.01 \\
\hline 5. & BMI & $\begin{array}{c}3.9 \\
4\end{array}$ & $\begin{array}{c}0.0 \\
3\end{array}$ & $\begin{array}{c}0.0 \\
2\end{array}$ & $\begin{array}{c}0.3 \\
4\end{array}$ & 4.35 \\
\hline 6. & BRIS & $\begin{array}{c}6.3 \\
4\end{array}$ & $\begin{array}{c}0.0 \\
4\end{array}$ & $\begin{array}{c}0.0 \\
7\end{array}$ & $\begin{array}{c}0.3 \\
9\end{array}$ & 6.85 \\
\hline 7. & BMS & $\begin{array}{c}6.0 \\
6\end{array}$ & $\begin{array}{c}0.0 \\
5\end{array}$ & $\begin{array}{c}0.1 \\
4\end{array}$ & $\begin{array}{c}0.4 \\
2\end{array}$ & 6.68 \\
\hline 8. & PBS & $\begin{array}{c}6.4 \\
7\end{array}$ & $\begin{array}{c}0.0 \\
2\end{array}$ & $\begin{array}{c}0.0 \\
2\end{array}$ & $\begin{array}{c}1.3 \\
7\end{array}$ & 7.89 \\
\hline 9. & BJBS & $\begin{array}{c}6.1 \\
9\end{array}$ & $\begin{array}{c}0.0 \\
1\end{array}$ & $\begin{array}{c}0.0 \\
5\end{array}$ & $\begin{array}{c}0.9 \\
2\end{array}$ & 7.19 \\
\hline 10. & BMSI & $\begin{array}{c}6.4 \\
3\end{array}$ & $\begin{array}{c}0.2 \\
4\end{array}$ & $\begin{array}{c}1.7 \\
2\end{array}$ & $\begin{array}{c}1.9 \\
4\end{array}$ & 10.34 \\
\hline
\end{tabular}

Sumber: Data diolah

Tahun 2013 menunjukkan sepuluh bank umum syariah tersebut masih dalam kategori tidak bangkrut, untuk tahun ini nilai Z-Score tertinggi masih ada pada Bank Maybank Syariah Indonesia dan nilai Z-Score terendah yaitu Bank Muamalat. Tabel 3. Perhitungan Z-Score BUS Tahun 2014

\begin{tabular}{|c|c|c|c|c|c|c|}
\hline $\begin{array}{l}\text { N } \\
\text { O. }\end{array}$ & $\begin{array}{c}\text { Bank } \\
\text { Umu } \\
\text { m } \\
\text { Syari } \\
\text { ah }\end{array}$ & $\begin{array}{l}6.56 \\
X_{1}\end{array}$ & $\begin{array}{l}3,26 \\
X_{2}\end{array}$ & $\begin{array}{l}6.72 \\
X_{3}\end{array}$ & $\begin{array}{c}1.0 \\
5 \\
X_{4}\end{array}$ & $\begin{array}{c}\text { Z- } \\
\text { Scor } \\
\text { e }\end{array}$ \\
\hline 1. & BNIS & 6.25 & 0.06 & 0.07 & $\begin{array}{c}0.6 \\
6\end{array}$ & 7.06 \\
\hline 2. & BSM & 6.32 & 0.16 & $\begin{array}{c}0.00 \\
1\end{array}$ & $\begin{array}{c}0.6 \\
2\end{array}$ & 7.11 \\
\hline 3. & BCAS & 6.08 & 0.04 & 0.03 & $\begin{array}{c}2.0 \\
2\end{array}$ & 8.19 \\
\hline 4. & BSB & 6.18 & $\begin{array}{c}- \\
0.09\end{array}$ & 0.01 & $\begin{array}{c}0.1 \\
1\end{array}$ & 6.22 \\
\hline 5. & BMI & $\begin{array}{c}6.00 \\
7\end{array}$ & 0.03 & 0.01 & $\begin{array}{c}0.4 \\
3\end{array}$ & 6.48 \\
\hline 6. & BRIS & 6.36 & 0.03 & $\begin{array}{c}0.00 \\
3\end{array}$ & $\begin{array}{c}3.2 \\
1\end{array}$ & 9.62 \\
\hline 7. & BMS & 6.05 & $\begin{array}{c}0.00 \\
5\end{array}$ & 0.02 & $\begin{array}{c}0.6 \\
3\end{array}$ & 6.71 \\
\hline 8. & PBS & 9.34 & 0.02 & 0.02 & $\begin{array}{c}1.5 \\
2\end{array}$ & $\begin{array}{c}10.9 \\
1\end{array}$ \\
\hline 9. & BJBS & 6.20 & 0.01 & 0.03 & $\begin{array}{c}1.1 \\
1\end{array}$ & 7.37 \\
\hline 10 & BMSI & 6.49 & 0.30 & 0.21 & $\begin{array}{c}2.1 \\
4\end{array}$ & 9.15 \\
\hline
\end{tabular}

Sumber: Data diolah 
Jati, et al/Jurnal Ekonomi Syariah Teori dan Terapan Vol. 5 No. 11 November 2018:937-954;

ANALISIS POTENSI KEBANGKRUTAN BANK UMUM SYARIAH DI INDONESIA PADA PERIODE 20122016 DENGAN METODE MULTIPLE DISCRIMINANT ANALYSIS

Tahun 2014 menunjukkan seluruh

bank umum syariah tetap berada pada kategori tidak bangkrut, hasil ini sama seperti tahun-tahun sebelumnya. Pada tahun ini Bank yang memiliki nilai Z-Score tertinggi dibandingkan bank yang lain adalah Panin Bank Syariah dengan nilai 10.91 dan bank yang memiliki nilai Z-Score terendah adalah Bank Syariah Bukopin dengan nilai 6.22.

Tabel 4. Perhitungan Z-Score BUS Tahun 2015

\begin{tabular}{|c|c|c|c|c|c|c|}
\hline No & $\begin{array}{c}\text { Bank } \\
\text { Umum } \\
\text { Syaria } \\
\text { h }\end{array}$ & $\begin{array}{c}6.5 \\
6 \\
X_{1}\end{array}$ & $\begin{array}{c}3,2 \\
6 \\
X_{2}\end{array}$ & $\begin{array}{c}6.7 \\
2 \\
X_{3}\end{array}$ & $\begin{array}{c}1.0 \\
5 \\
X_{4}\end{array}$ & $\begin{array}{c}\text { Z- } \\
\text { Scor } \\
e\end{array}$ \\
\hline 1. & BNIS & $\begin{array}{c}6.3 \\
3\end{array}$ & $\begin{array}{c}0.0 \\
8\end{array}$ & $\begin{array}{c}0.0 \\
8\end{array}$ & $\begin{array}{c}0.7 \\
0\end{array}$ & 7.21 \\
\hline 2. & BSM & $\begin{array}{c}6.2 \\
9\end{array}$ & $\begin{array}{c}0.1 \\
5\end{array}$ & $\begin{array}{c}0.0 \\
3\end{array}$ & $\begin{array}{c}0.5 \\
9\end{array}$ & 7.07 \\
\hline No & $\begin{array}{c}\text { Bank } \\
\text { Umum } \\
\text { Syaria } \\
\text { h }\end{array}$ & $\begin{array}{c}6.5 \\
6 \\
x_{1}\end{array}$ & $\begin{array}{c}3,2 \\
6 \\
X_{2}\end{array}$ & $\begin{array}{c}6.7 \\
2 \\
X_{3}\end{array}$ & $\begin{array}{c}1.0 \\
5 \\
X_{4}\end{array}$ & $\begin{array}{c}\text { Z- } \\
\text { Scor } \\
e\end{array}$ \\
\hline 3. & BCAS & $\begin{array}{c}6.1 \\
5\end{array}$ & $\begin{array}{c}0.0 \\
5\end{array}$ & $\begin{array}{c}0.0 \\
4\end{array}$ & $\begin{array}{c}2.8 \\
0\end{array}$ & 9.05 \\
\hline 4. & $B S B$ & $\begin{array}{c}6.2 \\
5\end{array}$ & $\begin{array}{c}0.0 \\
6\end{array}$ & $\begin{array}{c}0.0 \\
4\end{array}$ & $\begin{array}{c}0.1 \\
2\end{array}$ & 6.36 \\
\hline 5. & BMI & $\begin{array}{c}5.8 \\
5\end{array}$ & $\begin{array}{c}0.0 \\
1\end{array}$ & $\begin{array}{c}0.0 \\
1\end{array}$ & $\begin{array}{c}0.4 \\
1\end{array}$ & 6.30 \\
\hline 6. & BRIS & 6.3 & 0.0 & 0.0 & 0.3 & 6.85 \\
\hline
\end{tabular}

\begin{tabular}{|c|c|c|c|c|c|c|}
\hline & & 7 & 4 & 4 & 8 & \\
\hline 7. & BMS & 5.9 & 0.0 & 0.0 & 0.9 & 6.96 \\
4 & 1 & 2 & 8 & \\
\hline 8. & PBS & $\begin{array}{c}1.7 \\
7\end{array}$ & $\begin{array}{c}0.0 \\
6\end{array}$ & $\begin{array}{c}0.0 \\
7\end{array}$ & $\begin{array}{c}1.4 \\
4\end{array}$ & 3.35 \\
\hline 9. & BJBS & $\begin{array}{c}6.1 \\
7\end{array}$ & $\begin{array}{c}0.0 \\
1\end{array}$ & $\begin{array}{c}0.0 \\
1\end{array}$ & $\begin{array}{c}2.0 \\
8\end{array}$ & 8.29 \\
\hline 10. & BMSI & 6.0 & 0.2 & - & 2.8 & 7.66 \\
& 5 & 3 & 0 & 7 & \\
\hline
\end{tabular}

Sumber: Data diolah

Hasil perhitungan nilai Z-Score tahun 2015 menunjukkan nilai Z-Score tertinggi ada pada BCA Syariah dengan nilai 9.05 dan nilai Z-Score terendah ada pada Panin Bank Syariah dengan nilai 3.35 .

Tabel 5. Perhitungan Z-Score BUS Tahun 2016

\begin{tabular}{|c|c|c|c|c|c|c|}
\hline \multirow[b]{2}{*}{ No } & \multirow{2}{*}{$\begin{array}{l}\text { Bank } \\
\text { Umum } \\
\text { Syaria } \\
\text { h }\end{array}$} & \multicolumn{5}{|c|}{ Tahun (dalam jutaan rupiah) } \\
\hline & & $\begin{array}{c}6.5 \\
6 \\
X_{1}\end{array}$ & $\begin{array}{c}3,2 \\
6 \\
X_{2}\end{array}$ & $\begin{array}{c}6.7 \\
2 \\
X_{3}\end{array}$ & $\begin{array}{c}1.0 \\
5 \\
X_{4}\end{array}$ & $\begin{array}{c}\text { Z- } \\
\text { Scor } \\
\text { e }\end{array}$ \\
\hline 1. & BNIS & $\begin{array}{c}6.3 \\
6\end{array}$ & $\begin{array}{c}0.0 \\
9\end{array}$ & $\begin{array}{c}0.0 \\
8\end{array}$ & $\begin{array}{c}0.5 \\
5\end{array}$ & 7.11 \\
\hline 2. & BSM & $\begin{array}{c}6.1 \\
7\end{array}$ & $\begin{array}{c}0.0 \\
1\end{array}$ & $\begin{array}{c}0.0 \\
3\end{array}$ & $\begin{array}{c}0.5 \\
9\end{array}$ & 6.82 \\
\hline 3. & BCAS & 6.0 & 0.0 & 0.0 & 2.7 & 8.90 \\
\hline
\end{tabular}


Jati, et al/Jurnal Ekonomi Syariah Teori dan Terapan Vol. 5 No. 11 November 2018:937-954;

ANALISIS POTENSI KEBANGKRUTAN BANK UMUM SYARIAH DI INDONESIA PADA PERIODE 20122016 DENGAN METODE MULTIPLE DISCRIMINANT ANALYSIS

\begin{tabular}{|c|c|c|c|c|c|c|}
\hline & & 1 & 6 & 6 & 5 & \\
\hline 4. & BSB & $\begin{array}{c}6.2 \\
0\end{array}$ & $\begin{array}{r}0.0 \\
4\end{array}$ & $\begin{array}{c}0.0 \\
4\end{array}$ & $\begin{array}{c}0.1 \\
3\end{array}$ & 6.34 \\
\hline 5. & BMI & $\begin{array}{r}5.8 \\
2\end{array}$ & $\begin{array}{c}0.0 \\
1\end{array}$ & $\begin{array}{c}0.0 \\
1\end{array}$ & $\begin{array}{c}0.4 \\
0\end{array}$ & 6.25 \\
\hline 6. & BRIS & $\begin{array}{c}6.2 \\
6\end{array}$ & $\begin{array}{r}0.0 \\
6\end{array}$ & $\begin{array}{r}0.0 \\
5\end{array}$ & $\begin{array}{c}0.3 \\
1\end{array}$ & 6.70 \\
\hline 7. & BMS & $\begin{array}{c}6.0 \\
1\end{array}$ & $\begin{array}{c}0.6 \\
7\end{array}$ & $\begin{array}{c}0.1 \\
6\end{array}$ & $\begin{array}{c}1.7 \\
0\end{array}$ & 8.55 \\
\hline 8. & PBS & $\begin{array}{r}6.3 \\
2\end{array}$ & $\begin{array}{r}0.0 \\
6\end{array}$ & $\begin{array}{r}0.0 \\
2\end{array}$ & $\begin{array}{c}1.2 \\
2\end{array}$ & 7.63 \\
\hline 9. & BJBS & $\begin{array}{c}6.1 \\
2\end{array}$ & $\begin{array}{c}0.1 \\
6\end{array}$ & $\begin{array}{c}0.4 \\
9\end{array}$ & $\begin{array}{c}0.9 \\
7\end{array}$ & 6.44 \\
\hline 10. & BMSI & $\begin{array}{c}6.0 \\
6\end{array}$ & $\begin{array}{c}- \\
0.3 \\
9\end{array}$ & $\begin{array}{c}- \\
0.7 \\
2\end{array}$ & $\begin{array}{r}1.9 \\
2\end{array}$ & 6.86 \\
\hline
\end{tabular}

Sumber: Data diolah

Z-Score tertinggi ada pada BCA Syariah dengan nilai 8.90 dan nilai Z-Score terendah ada pada Bank Muamalat dengan nilai 6.25. Berdasarkan data pada Tabel 4.15 juga menunjukkan seluruh bank umum syariah masih berada pada kategori tidak bangkrut.
Berdasarkan hasil pengolahan menggunakan SPSS maka persamaan yang terbentuk adalah sebagai berikut:

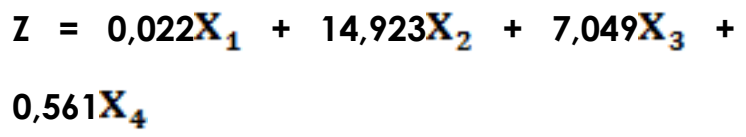

Nilai koefisien pada persamaan di atas di dapat pada tabel Test Equality of Group Means seperti tergambar pada tabel di bawah ini:

Tabel 6. Tests of Equality of Group Means

\begin{tabular}{|c|r|r|r|r|r|}
\hline & \multicolumn{1}{|c|}{$\begin{array}{c}\text { Wilks' } \\
\text { Lambda }\end{array}$} & $F$ & df1 & df2 & Sig. \\
\hline X1 & 1.000 & .022 & 1 & 48 & .882 \\
X2 & .763 & 14.923 & 1 & 48 & .000 \\
X3 & .872 & 7.049 & 1 & 48 & .011 \\
X4 & .988 & .561 & 1 & 48 & .457 \\
Sumber: data diolah \\
Dengan persamaan
\end{tabular}

terbentuk ini, kita dapat menghitung skor diskriminan dengan fungsi 1 pada setiap objek. Untuk memprediksi keanggotaan setiap objek, apakah masuk dalam kategori sehat atau tidak sehat, SPSS sudah memberikan hasil berupa data mengenai keanggotaan setiap objek berdasarkan peluang sebagaimana dipaparkan hasil perhitungan SPSS di bawah ini:

Tabel 7. Klasifikasi Kesehatan Bank* 
Jati, et al/Jurnal Ekonomi Syariah Teori dan Terapan Vol. 5 No. 11 November 2018:937-954;

ANALISIS POTENSI KEBANGKRUTAN BANK UMUM SYARIAH DI INDONESIA PADA PERIODE 20122016 DENGAN METODE MULTIPLE DISCRIMINANT ANALYSIS

\begin{tabular}{|cll|r|r|r|}
\hline \multirow{2}{*}{ Original } & & & Sehat & \\
& & 41 & 0 & 41 \\
& & Tidak Sehat & 1 & 8 & 9 \\
\cline { 2 - 5 } & Sehat & 100.0 & .0 & 100.0 \\
& & Tidak Sehat & 11.1 & 88.9 & 100.0 \\
\hline
\end{tabular}

a. $98.0 \%$ of original grouped cases correctly classified.

Berdasarkan hasil klasifikasi kesehatan bank, maka dapat diperoleh hasil bahwa sebagian besar bank umum syariah dalam kondisi sehat sebanyak 100,0\% dan yang tidak sehat sebanyak $11,1 \%$.

Sehingga dapat disimpulkan bahwa dengan menggunakan metode Multiple Discriminant Analysis bisa mengklasifikasikan bank umum syariah sehat dan tidak sehat.

$$
\text { Hasil penelitian menunjukkan }
$$

bahwa kondisi keuangan bank umum syariah menunjukkan hasil yang stabil. Hasil ini di dapat karena kegiatan usaha yang dilakukan baik dalam kegiatan penghimpunan dan penyaluran dana oleh bank syariah cenderung dilakukan secara aman. Maksud aman disini adalah bank syariah dalam melakukan transaksi berlandaskan pada asset dasar (underlying assets) dan kegiatan penyaluran dana bank syariah lebih ke arah sektor riil dalam perekonomian domestik. Berbeda dengan bank konvensional yang kegiatan usahanya cenderung lebih kearah spekulatif dengan melakukan transaksi-transaksi keuangan yang mempunyai resiko tinggi. Spekulatif disini maksudnya adalah dengan tergantung pada tingkat suku bunga, karena keuntungan terbesar bank konvensional didapatkan dari selisih antara besarnya bunga yang dikenakan kepada para peminjam dana dengan imbalan bunga yang diberikan kepada nasabah penyimpan

\section{SIMPULAN}

Penelitian ini dilakukan untuk

menilai kesehatan BUSN di Indonesia dengan menggunakan metode Multiple Descriminant Analysis. Berdasarkan hasil penelitian yang telah dibahas pada Bab IV, maka dapat disimpulan sebagai berikut:

1. Berdasarkan hasil klasifikasi kesehatan bank, maka dapat diperoleh hasil sebagian besar bank umum syariah dalam kondisi sehat sebanyak 100,0\% dan yang tidak sehat sebanyak 11,1\%. Sehingga dapat disimpulkan bahwa dengan menggunakan metode Multiple Discriminant Analysis bisa mengklasifikasikan bank umum syariah sehat dan tidak sehat.

2. Tahun 2012 sampai dengan tahun 2016 seluruh bank umum syariah mempunyai nilai di atas 2.90, nilai tersebut merupakan kriteria pada model Z-Score modifikasi yang menyatakan bahwa perusahaan dalam kondisi yang sehat. 
Jati, et al/Jurnal Ekonomi Syariah Teori dan Terapan Vol. 5 No. 11 November 2018:937-954;

ANALISIS POTENSI KEBANGKRUTAN BANK UMUM SYARIAH DI INDONESIA PADA PERIODE 20122016 DENGAN METODE MULTIPLE DISCRIMINANT ANALYSIS

3. Variabel yang paling signifikan semua risiko yang dihadapi dalam industri

berpengaruh adalah Retained Earning to

Total Asset dan Earning Before Tax to Total

Asset.

4. Nilai Z-Score tertinggi tahun 2012 dan 2013 ada pada Bank Maybank Syariah Indonesia, tahun 2014 nilai Z-Score tertinggi adalah Panin Bank Syariah dan untuk tahun 2015 dan 2016 nilai Z-Score tertinggi ada pada BCA Syariah.

5. Hasil penelitian menunjukkan bahwa kondisi keuangan bank umum syariah menunjukkan hasil yang fluktuatif . Penelitian ini juga menunjukkan bahwa kesehatan bank umum syariah tidak terganggu meskipun krisis ekonomi sedang melanda Indonesia. Hasil penelitian juga menunjukkan bahwa bank syariah adalah bank yang aman, sehat dan dapat dipercaya oleh masyarakat untuk menyimpan uang atau menginvestasikan dana yang dimiliki. Altman Z-Score memang dapat digunakan sebagai sistem pencegahan dini untuk memprediksi potensi kebangkrutan pada perusahaan. Alasan pemilihan model Altman Z-Score modifikasi ini karena bank syariah berbeda dengan perusahaan manufaktur jadi bank syariah tidak cocok menggunakan model Altman Z-Score original ataupun Altman Z-Score revisi.

\section{SARAN}

Saran untuk bank umum syariah adalah untuk dapat terus mengontrol perbankan. Dalam situasi perekonomian yang lesu variabel yang harus diperhatikan yaitu Retained Earning to Total Assets dan Earning Before Tax to Total Asset. Ketika risiko dapat di kendalikan dengan baik dan benar, hal itu akan meminimalisir terjadinya masalahmasalah, terutama likuiditas yang sering berujung pada kebangkrutan. Dan ketika hal tersebut dapat terwujud, maka kepercayaan masyarakat pada bank syariah pun bisa meningkat.

\section{DAFTAR PUSTAKA}

Departemen Agama RI. 2008. Al-Qur'an Terjemahan (Revisi Terbaru) dengan transliterasi Arab-Latin. Semarang CV. As-Syifa'

Altman, Edward I. 1968. Financial Ratios, Discriminant Analysis And The Prediction of Corporate Bankruptcy. The Journal of Finance

Altman, Edward I. 2000. Predicting Financial Distress of Companies: Revisiting The Z-Score and ZETA® Models. The Journal of Finance

Anshori, Muslich dan Sri Iswati. 2009. Metodologi Penelitian Kuantitatif. Surabaya: Airlangga University Press (AUP)

Kurniasih, Etha dan Muhammad Akhyar Adnan. 2000. Analisa Tingkat Kesehatan Perusahaan Untuk Memprediksi Potensi Kebangkrutan Dengan Pendekatan Altman. Jurnal 
Jati, et al/Jurnal Ekonomi Syariah Teori dan Terapan Vol. 5 No. 11 November 2018:937-954;

ANALISIS POTENSI KEBANGKRUTAN BANK UMUM SYARIAH DI INDONESIA PADA PERIODE 20122016 DENGAN METODE MULTIPLE DISCRIMINANT ANALYSIS

Akuntansi dan Auditing

Indonesia, Vol. 4, No. 2.

Universitas Islam Indonesia

Lukviarman, Niki dan Ayu Suci Ramadhani.

2009. Perbandingan Analisis

Prediksi Kebangkrutan

Menggunakan Model Altman

Pertama, Altman Revisi dan

Altman Modifikasi Dengan

Ukuran Dan Umur Perusahaan

Sebagai Variabel Penjelas (Studi

Pada Perusahaan Manufaktur

yang terdaftar di BEI / Jurnal

Siasat Bisnis Vol.13,no.1.

Universitas Andalas

Muhamad. 2014. Manajemen Dana Bank

Syariah. Jakarta: PT

Rajagrafindo Persada.

Pass, Christopher dan Bryan Lowes. 2001.

Kamus Lengkap Ekonomi.

Jakarta: Erlangga

Republik Indonesia. 2008. Undang-Undang

Republik Indonesia Nomor 21

Tahun 2008 Tentang Perbankan

Syariah. Jakarta: DPR

Sartono, Agus. 2008. Manajemen Kevangan Teori dan Aplikasi. Yogyakarta: BPFE

Simamora, Bilson. 2005. Analisis Multivariat

Pemasaran. Jakarta: PT

Gramedia Pustaka Utama

ST Ibrah Mustafa Kamal. 2012. Analisis

Prediksi Kebangkrutan Pada

Perusahaan Perbankan Go

Public Di Bursa Efek Indonesia

(dengan menggunakan model

Altman Z-score), skripsi Strata
1. Universitas Hasanudin

Makassar.

Supardi. 2005. Metodologi Penelitian

Ekonomi dan Bisnis.

Yogyakarta:UII Press

Widarjono, Agus. 2010. Analisis Statistika Multivariat Terapan. Yogyakarta: UPP STIM YKPN

http://www.bankmuamalat.co.id/profilbank-muamalat diakses pada tanggal 20 Maret 2017 